\title{
E-Ticaret Sitelerinin Kullanılabilirliğinin AHP ve TOPSİS Yöntemleriyle Karşılaştırılması
}

\author{
Muhammet Enis Bulak ${ }^{1}$, Orkun Kozanoğlu², Şule Nur Aydoğduoğlu ${ }^{3}$, Fatmanur Göçer ${ }^{4}$, Rabia Algül ${ }^{5}$ \\ 1 Üsküdar Üniversitesi, Mühendislik ve Doğa Bilimleri Fakültesi, Endüstri Mühendisliği Bölümü, İstanbul, Türkiye (ORCID: 0000-0003-3784-7830) \\ 2 Üsküdar Üniversitesi, Mühendislik ve Doğa Bilimleri Fakültesi, Endüstri Mühendisliği Bölümü, İstanbul, Türkiye (ORCID: 0000-0003-1006-4879) \\ ${ }^{3}$ Üsküdar Üniversitesi, Mühendislik ve Doğa Bilimleri Fakültesi, Endüstri Mühendisliği Bölümü, İstanbul, Türkiye (ORCID: 0000-0003-0795-0183) \\ ${ }^{4}$ Üsküdar Üniversitesi, Mühendislik ve Doğa Bilimleri Fakültesi, Endüstri Mühendisliği Bölümü, İstanbul, Türkiye (ORCID: 0000-0001-8063-2566) \\ 5 Üsküdar Üniversitesi, Mühendislik ve Doğa Bilimleri Fakültesi, Endüstri Mühendisliği Bölümü, İstanbul, Türkiye (ORCID: 0000-0003-3871-9849)
}

(International Congress on Human-Computer Interaction, Optimization and Robotic Applications (HORA) 2021 - 11-13 June 2021)

(DOI: $10.31590 /$ ejosat.963658)

ATIF/REFERENCE: Enis Bulak,M., Kozanoglu, O., Nur Aydoğduoğlu,Ş., Göçer,F., \& Algül,R. (2021). E-Ticaret Sitelerinin Kullanılabilirliğinin AHP ve TOPSİS Yöntemleriyle Karşılaştırılması. European Journal of Science and Technology, (26), 493-509.

$\ddot{O} z$

Günümüz rekabetçi koşullarında organizasyonlar daha iyi servis üretmek adına süreçlerine dijital değişimi adapte etmek zorundadır. İşletmelerin ise e-ticarete olan ihtiyaçları gün geçtikçe artmış ve online satış platformlarının kullanılabilirliği önemli bir konu haline gelmiştir. Bu doğrultuda, kullanıcı trafiği en yoğun ilk 10 e-ticaret sitesi ele alınarak 366 farklı kullanıcıyla anket çalışması yapılmıştır. Toplanan veri AHP ve TOPSIS yöntemlerine girdi sağlayarak web sitelerinin kullanılabilirlik performansını etkileyen faktörlerin önem dereceleri bulunmuş ve her iki yöntem için e-ticaret sitelerinin kullanılabilirlik puanları hesaplanmıştır. Çalışmanın sonucuna göre site navigasyonu kullanılabilirlik performansını etkileyen en önemli faktör olarak bulunmuştur. AHP yöntemine göre N11 ve Hepsiburada kullanılabilirlik açısından en iyi performansı sergileyen e-ticaret platformları olurken, sırasıyla Sahibinden ve Amazon websiteleri ise TOPSİS yönteminde en yüksek puana ulaşmıştır. Ayrıca, bu çalışma e-ticaret websitelerinin tasarımcılarına kullanıcı odaklı bir yol haritası sunarken karar vericiler için ise yönetimsel uygulamalar sağlamaktadır.

Anahtar Kelimeler: Kullanılabilirlik, Kullanıcı arayüzü, E-ticaret, AHP, TOPSíS

\section{Benchmarking Usability Performance of E-Commerce Websites with AHP and TOPSIS Methods}

\begin{abstract}
Organizations have to adapt the digital transformation to their processes for producing better services in the competitive business world. The needs of e-commerce businesses are increasing day by day, and online sales platforms' usability becomes an important issue. In this context, a survey was conducted with 366 different users by taking the top 10 e-commerce sites with the highest user traffic. The collected data provided input to the AHP and TOPSIS methods, and the importance levels of the factors affecting the usability performance of the websites were found. The usability scores of e-commerce sites were calculated for both methods. The results showed that site navigation is the most important factor affecting usability performance. Based on the AHP method, N11 and Hepsiburada were the best e-commerce platforms in terms of usability, while Sahibinden and Amazon websites reached the highest score in the TOPSIS method, respectively. Also, this study provides a user-oriented roadmap to the designers of e-commerce websites, while providing administrative applications for decision-makers.
\end{abstract}

Keywords: Usability, User Interface, E-commerce, AHP, TOPSIS

\footnotetext{
* Sorumlu Yazar: Üsküdar Üniversitesi, Mühendislik ve Doğa Bilimleri Fakültesi, Endüstri Mühendisliği Bölümü, İstanbul, Türkiye, ORCID: 00000003-3784-7830, muhammetenis.bulak@uskudar.edu.tr
} 


\section{Giriş}

Gelişen toplumların var olmalarını devam ettirebilmeleri için ihtiyaç duyduğu en önemli kaynak "bilgi" dir. Geçmişten günümüze uzanan tarihsel süreç içerisinde toplumların nitelikli bilgi üretme ve bunun etkin doğrultularda kullanılması için çeşitli olanaklar geliştirilmiştir. 21.yüzyılın sunduğu çoklu işlevselliğe sahip ürünlerin (tablet, akıllı telefon vb.) karmaşıklı̆g hem sosyal alanda hem ekonomik alanda teknolojinin kullanımını yaygınlaştırmıştır. $\mathrm{Bu}$ cihazların kullanımının yaygınlaşması hanelere ulaşan internet kullanım oranını artırmıştır.

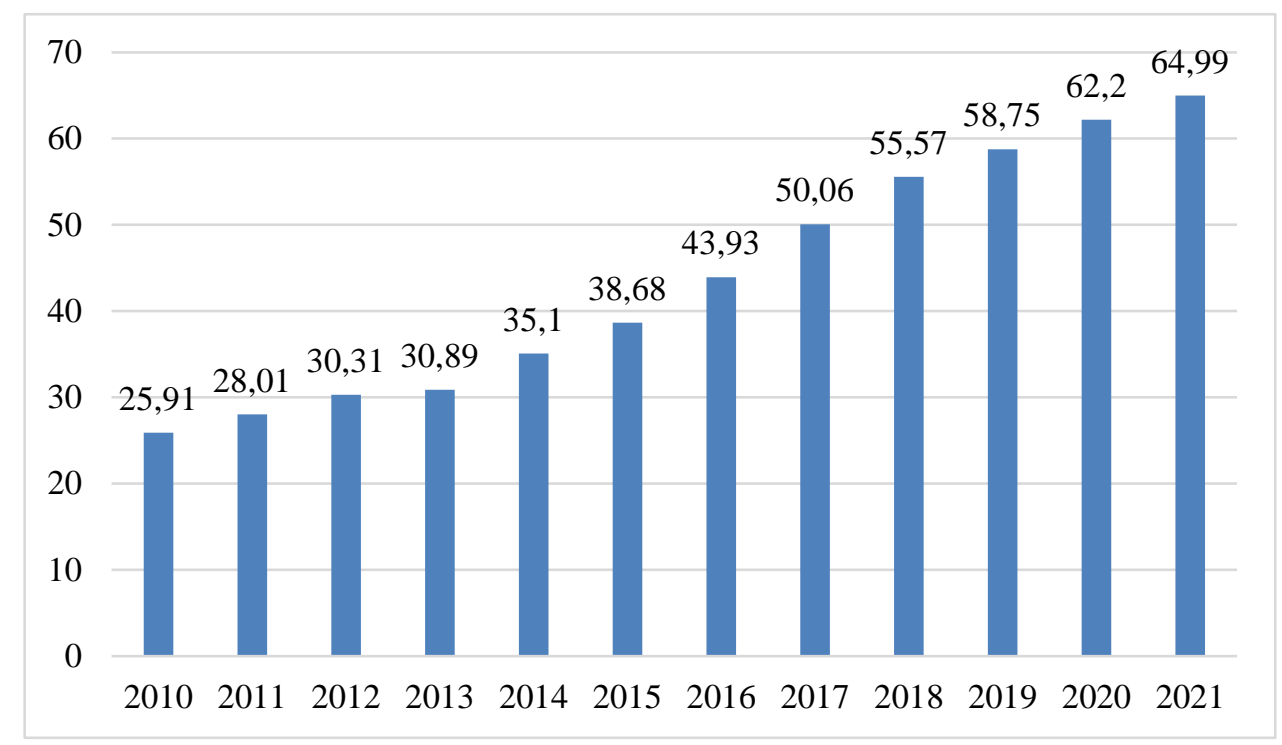

Şekil 1. 2010-2021 Yılı Türkiye Internet Kullanıcı Oranı (Statista, 2021)

Şekil 1 Türkiye' de son 11 yıl içerisindeki artan internet kullanım oranlarını göstermektedir. 2010 y1lında bu oran \%25,91 10 yıl içinde \%64,99'a ulaşmıştır. 2021 yılında ise Türkiye'deki internet kullanıcı tahmini sayısı 65,0 milyon olarak bulunmuştur (Statista,2021).

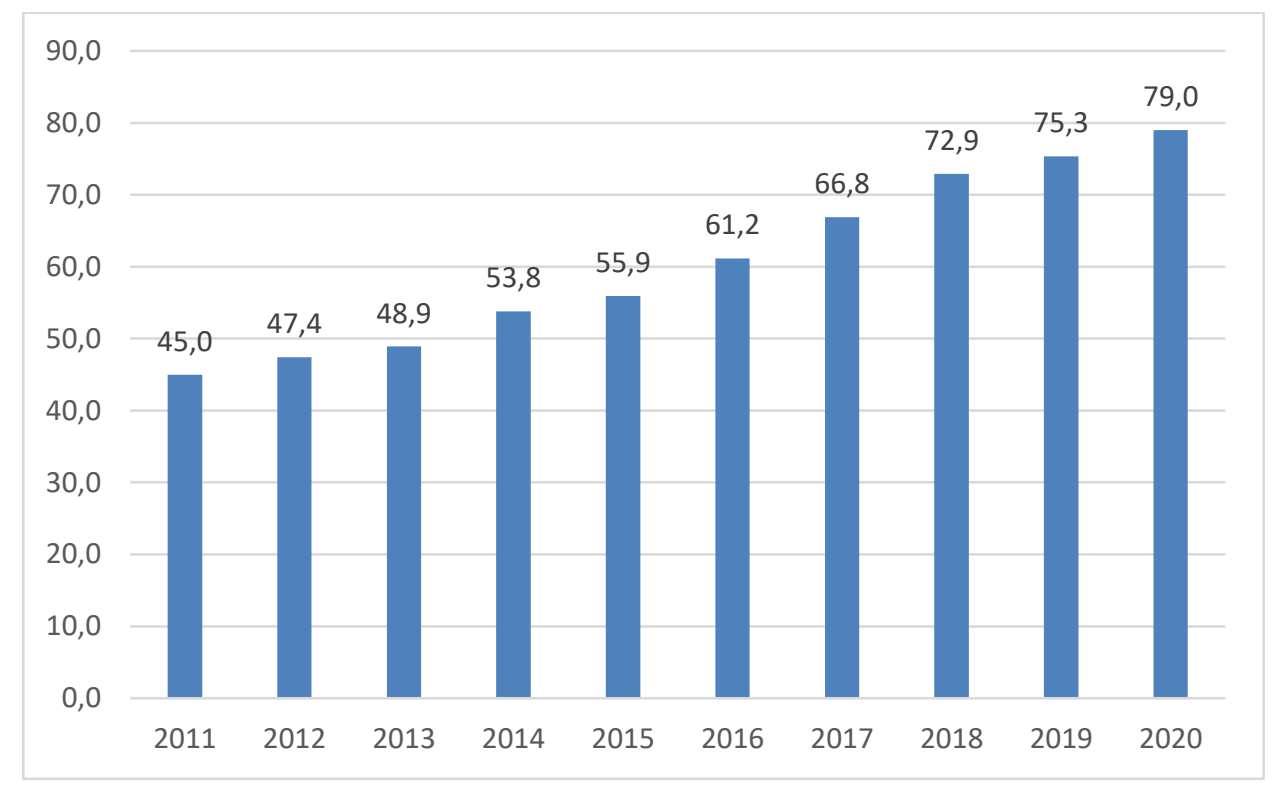

Şekil 2. Hanelerde Bilişim Kullanım Oranı (Tüik, 2020)

Şekil 2'ye bakıldığında ise 2011-2020 y1lları arası internetin hanelerde bulunma oran 2011 yılında \%45 iken bu oran 2020 yılında \%79 ulaşmışıı. Hızla gelişen teknoloji şüphesiz insan hayatında birçok yenilik oluşturmaktadır. Günümüzde bu yeniliklere internet ve beraberindeki faydalar öncülük etmektedir. İnternet ve beraberindeki yeni içgörüler içerdiği değişiklikle, insanların bugüne kadar var olan davranışlarını tamamen değiştirmektedir. $\mathrm{Bu}$ kavramlardan biri olan e-ticaret bazı kesimler için ise oldukça yenidir (Doğaner, 2007). İnternetin yaşamın çeşitli alanlarında yaygınlaşması, sosyal yaşam kalitesini artırırken tüketicilerin davranışlarını, alışkanlıklarını ve alışveriş tarzlarını önemli ölçüde değiş̧irmiştir. Bu süreçte e-ticaret adı verilen web siteleri üzerinden alışveriş çok önemli hale gelmiştir.

Müşterilere ulaşmada internet kullanmanın işletmeler için önemi giderek artmaktadır (Yılmaz ve Tümtürk, 2015). Geçtiğimiz yüzyılda birçok perakende mağazacılık formatı insan yaşamına dahil olmuştur. Ancak, yeni yüzyllla birlikte, perakende alışverişin yeni bir şekli olan çevrimiçi alışveriş (sanal alışveriş) 
popüler hale gelmiştir. Modern bir pazarlama aracı olan sanal mağazacılık, işletmeler tarafından tüketicilere ulaşmak için kullanılan önemli bir rekabet aracı haline gelmiştir. Bu şekilde fark yaratan işletmeler, şüphesiz, müşterilerin satın alma davranışı ile çevrimiçi mağaza atmosferi arasındaki ilişkiyi en iyi tanımlar (Doğaner, 2007).

Web sitelerinin ara yüzü teknoloji açısından kolayca kullanılabilir bir seviyede olduğunda ise kullanıcılarla etkileşim artar. $\mathrm{Bu}$ doğrultuda Müşterilerin siteyi kullanırken az çaba harcamaları alışveriş sadakatini olumlu yönde etkiler. Web sitesinin kullanım kolaylığı, yüz yüze etkileşime alternatif olduğundan sitedeki alıcıların satın alma niyetlerinide olumlu yönde ve önemli ölçüde etkilemektedir (Lee vd., 2013).

Lu ve Yeung (1998)'e göre, kabul edilebilirlilik sisteminin önemli bir faktörü olan işlevsellik ve kullanılabilirlik, kullanışlılığın alt özellikleridir. İnternet alışverişini tercih eden kullanıcılar fonksiyonel ve kullanışlı ürünleri daha sık kullanma eğilimindedir. Sadece işlevsellik odaklı tasarımlar kullanılabilirlik ihtiyaçlarını karşılayamaz (Klein ve Seffah, 2005). Sonuç olarak, bu ilişki web tasarımı süreçlerinde hem kullanılabilirlik hem de işlevsellik açısından önemli bir faktördür (Weir, 2007). Bu nedenle bu araştırma,Türkiye'de faaliyet gösteren e-ticaret web siteleri için kullanılabilirlik faktörlerinin önemini ve kullanılabilirliğin çeşitli özellikleri ile açıklanan alt kriterler üzerindeki detaylı ilişkileri analiz etmeyi amaçlamaktadır.

Kullanılabilirlik faktörleri aracılığıyla web sitelerini incelemek, kuruluşların amaçlarını, arayüz yapılarını ve hizmetlerini geliştirmesi ve güncellemesi açısından yararlı olabilir (Çalışır vd., 2009). Kullanılabilirlik, bir web sitesinin kullanıcıların işlevlerini kolay ve uygun bir şekilde kullanmasını kolaylaştırdığı ölçüde artar. Ticari web sitesinin başarısında en kritik faktör kullanılabilirliktir. Bu faktör müşterilerin güvenini kazanmada ve sürdürmede de önemli bir role sahiptir (Roy vd., 2001; Casalo vd., 2007).

Elektronik Ticaret (e-ticaret), kurulduğu 1984 yılından bu yana web 'deki alışveriş sayfalarının tasarımını etkilemede kullanılabilirliğin kritik bir rol oynadığı bir alan olmuştur (Ozok ve Wei,2010). Kullanılabilirlik, web sitesinin ürün ve hizmetleri hakkında yeterli bilgi sağlayıp sağlayamayacağı anlamına gelirken, kullanım kolaylığı ve eğlence, web sitesinin müşteriler için kolay ve keyifli olmasını ifade eder (Loiacono, 2002; Toklu, 2019). Tablo 1'de ise E-Ticaret siteleri için kullanılabilirlik kavramının değerlendirildiği çalışmalara yer verilmiştir.

\section{Tablo 1. E-ticaret Sitelerinin Kullanılabilirliğinin Değerlendirilmesine İlişkin Araştırmalar}

\begin{tabular}{|c|c|}
\hline Yazarlar & Amaç ve Bulgular \\
\hline Arora ve Gupta,2016 & $\begin{array}{l}\text { Bu çalışmada E-ticaret işini etkileyen temel faktörlerin bulunması amaçlanmıştır. Ürün güvencesi, e-ticaret web sitesinin seçiminde dikkate alınan en } \\
\text { önemli parametre olarak görülmüştür. } \\
\text { Fiyatlandırma ise kullanıcılar tarafından istenen ikinci önemli kriterdir. }\end{array}$ \\
\hline Nagpal vd.,2016 & $\begin{array}{l}\text { Bu makalede, sırasıyla bulanık AHP ve entropi yöntemi kullanılarak kullanılabilirliği değerlendiren nesnel ve öznel yaklaşımın entegre edilmesi için yeni } \\
\text { bir metrik önerildi. Entropi yaklaşımı, ana katkıda bulunan Yanı Süresi'ni (RT) önerirken, FAHP, akademik web sitelerinin kullanılabilirliğinin } \\
\text { değerlendirilmesinde ana katkıda bulunan olarak Gezinme Kolaylığı'nı (EON) önermektedir. Birleşik yaklaşım, yüksek öğrenimin akademik web } \\
\text { sitelerinin kullanılabilirliğinin değerlendirilmesinde ana katkıda bulunan RT olarak ortaya çıkarmaktadır. }\end{array}$ \\
\hline Kahraman vd.,2017 & $\begin{array}{l}\text { Bu çalışmada, B2C firmaları arasında seçim için tereddütlü bulanık bir dil hiyerarşisi süreci yöntemi önerilmiştir. Verimli bir seçim için, veri tabanlarında } \\
\text { kapsamlı bir araştırma sonucunda belirlenen } 7 \text { ana kriter altında } 21 \text { alt kriter ele alınarak } 5 \text { uluslararas1 B2C firmasının e-Pazar yerleri ana ve alt kriterlere } \\
\text { göre karşılaştırılmıştır. Duyarlılık analizi, elde edilen sıralamaların kriter ağırlıklarındaki değişikliklere dayanıklı olduğunu göstermiştir. }\end{array}$ \\
\hline Roy vd., 2017 & $\begin{array}{l}\text { Bu makale, bir web sitesinin kullanılabilirlik puanını ölçmek için AHP tabanlı kullanılabilirlik değerlendirme tekniğini dikkate almaktadır. Önerilen } \\
\text { yaklaşımla elde edilen sonucun WAMMI raporundan elde edilen sonuçla tutarlı olduğu görülmüştür. Doğruluk, yaklaşımı için kullanılan veri setinin } \\
\text { aynısı dikkate alınarak WAMMI tarafından onaylanmıştır. }\end{array}$ \\
\hline Rouyendegh vd.,2018 & $\begin{array}{l}\text { Bu çalışma, E-ticaret web sitesi (EWS) performansının ölçülmesi ve değerlendirilmesi için Analitik hiyerarşi süreci ve İdeal Çözüme Benzerlik ile Tercih } \\
\text { Sıralaması için Sezgisel Bulanık Tekniğin hibrit bir çerçevesini sunmaktadır. Bu çalışmada, belirsizlik ve kararsızlığı hesaba katmak için Türkiye'deki üç } \\
\text { EWS'yi bulanık ortamlar altında değerlendiren hem AHP hem de IFT modellerini kullanan hibrit bir model sunulmuștur. }\end{array}$ \\
\hline Yağl1,2018 & $\begin{array}{l}\text { Bu çalısmanın amacı teknoloji mağazalarının internet sitesi kalitesini değerlendirmede kalite tabanlı bir model oluşturmaktır. Klasik AHP'nin } \\
\text { kullanılmasıyla elde edilen sonuçlar neticesinde güvenilirliğin en önemli kriter olduğu ve güvenilirliği; içerik, fonksiyonel uygunluk ve kullanılabilirliğin } \\
\text { takip ettiği görülmektedir. }\end{array}$ \\
\hline Özkan vd.,2019 & $\begin{array}{l}\text { Bu çalışmada, literatürdeki uzman değerlendirmeleri ve yeniliklerin yanı sıra, farklı kriterler ve ağırlıklandırma yaklaşımlarındaki değişiklikler kullanılarak } \\
\text { iyileştirilmesi gerekli olduğu düşünülen bir karşış̧ırma amaçlanmı̧ı̧tır. İki TOPSIS yaklaşımının yakınlık katsayılarına göre ikinci alternatif her zaman bir } \\
\text { numara iken birinci ve üçüncü alternatifin yerleri iki yöntemde değişmiştir. Birinci ve üçüncü alternatifler arasındaki sıralama değişiklikleri, tasarımcıların } \\
\text { ve müşterilerin davranışları arasındaki farklılıklar açısından değerlendirilebilirken farklı beklentiler ve farklı ölçüt ağırlıkları, sıralamalarda farklılaşmaya } \\
\text { neden olmuştur. }\end{array}$ \\
\hline Aziz vd.,2019 & $\begin{array}{l}\text { Bu araştırma, web sitesi kalite kriterlerinin önceliğini belirlemeyi ve Analitik Hiyerarşik Süreç (AHP) kullanarak Endonezya'daki } 10 \text { e-ticaret web sitesinin } \\
\text { kalitesini ölçmek için belirlenen kriterleri birleştirmeyi amaçlamaktadır. Ayrıca bu çalışma, C2C web sitesi bağlamında web sitesi kalitesi için en önemli } \\
\text { kriterin kullanılabilirlik, en düşük önceliğin ise işaretleme doğrulaması olduğunu ortaya koymaktadır. }\end{array}$ \\
\hline Adepoju vd.,2020 & $\begin{array}{l}\text { Bu bilimsel makalenin amacı, web sitelerinin kullanılabilirliğinin değerlendirmesinde ÇKKV yaklaşımlarının uygulanmasına ilişkin literatürdeki eğilimleri } \\
\text { belirlemektir. Saygın dergilerden ve konferans bildirilerinden alınan toplam } 63 \text { bilimsel makale dikkatle analiz edilmiş web sitesi kullanılabilirlik } \\
\text { değerlendirmesi için çeşitli bireysel ve entegre yöntemler önerilmiştir. Sonuç olarak, kullanılabilirlik açısından en önemli kriterler kullanım kolaylığı ve } \\
\text { gezilebilirlik olmasına rağmen, kalite açısından en popüler kriter kullanılabilirliktir. }\end{array}$ \\
\hline Lai vd.,2020 & $\begin{array}{l}\text { Araştırma sonuçları, web siteleri için en önemli beş başarı faktörünün iyi itibar, işlem güvenliği, kullanım kolaylığı, promosyon ve çeşitlendirilmiş } \\
\text { seçenekler olduğunu göstermiştir, bu da karar vericilerin mevcut rekabetçi iş senaryosunda etkili web siteleri tasarlamaları için yol gösterici olmuştur. }\end{array}$ \\
\hline
\end{tabular}

E-ticaret sitelerinin kullanılabilirliğini etkileyen birçok faktör vardır. Bu faktörler en iyi çoklu karar verme yöntemleri ile değerlendirilebilir ve hangi faktörün daha önemli olduğuna karar verilebilir. Bu çalışma, AHP ve TOPSİS yöntemini kullanarak çevrimiçi alışveriş hizmeti veren e-ticaret web sitelerinin performans değerlendirmesini 'Çok Kriterli Karar Verme' (ÇKVV) ile analiz etmeyi amaçlamaktadır.
Çalışmanın devamında AHP ve TOPSİS yöntemini içeren çalışmalara yer verilmiştir. Daha sonra kullanılan çoklu karar verme yöntemlerinden AHP ve TOPSİS hakkında genel bilgiler ve nasıl uygulanacağı hakkında bilgiler verilmiştir. Kriter ağırlıklarını belirlemede ve yöntemin tutarlılık oranlarını doğru değerlendirmesi açısından AHP, alternatif sıralamaları ile hesapların anlaşılır olması gibi sebeplerden dolayı ise TOPSISS yöntemi seçilmiştir. Bu kısımlardan sonra, çalışmada kullanılan e-ticaret siteleri belirlenmiş ve e-ticaret web sitelerinin 
performansının ölçülmesinde kullanılan performans kriterleri ve kriterlerin nasıl belirlendiği tanımlanmıştır. Bu kriterlere göre AHP ve TOPSİS modelleri oluşturularak en sık kullanılan 10 eticaret sitesi değerlendirmeye alınmıştır. Dördüncü bölümde, sonuçlar değerlendirilmiş ve belirlenen kriterlerin e-ticaret sitelerinin kullanılabilirliğine hangi ölçüde etki ettiği belirlenmiştir. Son bölümde ise e-ticaret sitelerine yönelik iyileştirme önerileri ve planlanan çalışmalara yer verilmiştir.

\section{Materyal ve Metot}

\section{1. Çok Kriterli Karar Verme Yöntemleri (ÇKKV)}

Hayatımızın her döneminde birçok alternatif arasından seçim yaptığımız kararlar bulunmaktadır. Aldığımız her karar için bir alternatifi seçerek diğer alternatifleri eleriz (Kardam, 2001). Günümüzde devamlı değişen ve zamanla zorlaşan çalışma şartları insan, kurum ve işletmeleri devamlı olarak karar vermede iyi ve başarılı olanı seçmeye şartlandırmaktadır (Forman ve Gass, 2001). Karar verme sürecine sayısal yöntemlerin veya karar teknolojilerinin (karar analizleri, modelleri, algoritmaları ve teorileri) olumlu bir etkisi bulunmaktadir (Carlson ve Fuller, 1996).

Karar verme aşamasında Çok Kriterli Karar Verme (ÇKKV) yöntemlerinin kullanılması yöneticilere alternatifleri değerlendirmede yardımcı olmakta ve işletme kaynaklarının daha verimli kullanılmasını sağlamaktadır. ÇKKV yöntemleri ölçülebilen ve ölçülemeyen birçok stratejik ve operasyonel faktörü aynı anda değerlendirme imkânı sağlayan, aynı zamanda karar verme sürecine çok sayıda kişiyi dâhil edebilen bir analitik yöntemdir (Dağdeviren vd.,2005).
Bu karar aşamasında çoklu karar verme yöntemlerinden olan AHP ve TOPSIS, süreci en çok hızlandıran yöntemlerdir. Çalışmada kullanılan AHP ve TOPSİS yöntemleri aşağıda açıklanmıştır.

\subsection{Analitik Hiyerarşi Süreci (AHP)}

AHP, bileşenleri arasında karmaşıı ilişkiler bulunan sistemlere ait karar problemlerinde; sistemi alt sistemleriyle ilişkili hiyerarşik bir yapıda oldukça basitleştirerek ifade edip, sezgisel ve mantıksal düşünceyle irdeleyebilen ve bunların modellenmelerine olanak sağlayan bir yaklaşımdır (Ünal, 2008).

AHP, çok kriterli karar verme problemlerinin; ana hedef, kriterler, alt kriterler ve alternatifler arasındaki ilişkiyi gösteren, hiyerarşik bir yapıda modellenebilmesine olanak veren bir yöntemdir. $\mathrm{Bu}$ yöntemle, birçok değerlendirme kriterin rol oynadığı karar problemlerinde, kriterlerin amaca katkısının belirlenebilmesi için kriter ağırlıkları hesaplanabilir ve uygun karar alternatifi seçilebilmektedir (Dinçer, 2011).

\subsubsection{Analitik Hiyerarşi Sürecinin (AHP) Adımları}

Birçok uygulamaya esas oluşturan AHP'nin 7 adımı aşağıda sıralanmıştır.

\section{Adım 1: Hiyerarşik Yapının Kurulması}

AHP'nin ilk adımını, karar probleminin anlaşılabilir ve değerlendirilebilir olabilmesi için hiyerarşik olarak düzenlenmesi oluşturmaktadır. Bunun için Şekil 3'de görüldüğü gibi karar probleminin ana hedefi, kriterler, alt kriterler ve alternatifleri hiyerarşik bir yapıda hazırlanır.

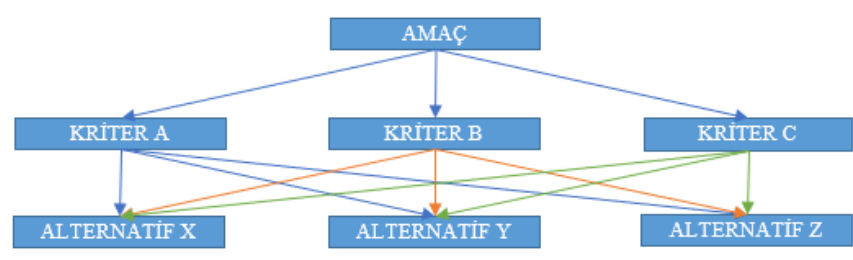

Şekil 3. AHP Modeli

\section{Adım 2: Önceliklerin Belirlenmesi}

Saaty, Tablo 2'de görüldüğü gibi karar kriterlerini ve karar kriterlerinin ikili karşılaştırmasında kullanılan bir ölçek geliştirmiştir. Bu ölçekle, karar kriterleri ve her bir karar kriterine göre karar seçenekleri ikili karşılaştırmalarla 1 ile 9 arasında bir değerle değerlendirilmiştir.
Tablo 2. İkili Karşılaştırma Yönteminde Kullanılan 1-9 Skalası

\begin{tabular}{|l|l|}
\hline DERECELER & TANIM \\
\hline 1 & Eşit Önemli \\
\hline 3 & Biraz Daha Fazla Önemli \\
\hline 5 & Kuvvetli Derece Önemli \\
\hline 7 & Çok Kuvvetli Derece Önemli \\
\hline 9 & Aşırı Derece Önemli \\
\hline $2-4-6-8$ & Uzlaşma (Ortalama Değerler) \\
\hline
\end{tabular}

\section{Adım 3: İkili Karşılaştırma Matrisi}

Farklı kriterlerin ikili karşılaştırmaları Tablo 3'de görüldüğü gibidir. Burada n kriter, $i=1,2, . ., n$ 'e kadar ve $j=1,2, . .$, n'e kadar olmak üzere satır ve sütunlarda sıralanarak karşılaştırma matrisini 
oluşturmaktadır. Matristeki wi/wj terimi, karşılaştırma matrisinde amaca ulaşmada i. kriterin j. kriterden ne kadar daha önemli olduğunu ifade etmektedir.

Tablo 3: Kriterler için İkili Karşılaştırma Matrisi Oluşturulması

\begin{tabular}{|l|l|l|l|l|}
\cline { 2 - 5 } \multicolumn{1}{c|}{} & Kriter 1 & Kriter 2 & $\ldots \ldots \ldots$ & Kriter n \\
\hline Kriter 1 & $\mathrm{~W} 1 / \mathrm{W} 1$ & $\mathrm{~W} 1 / \mathrm{W} 2$ & $\ldots \ldots \ldots$ & $\mathrm{W} 1 / \mathrm{Wn}$ \\
\hline Kriter 2 & $\mathrm{~W} 2 / \mathrm{W} 1$ & $\mathrm{~W} 2 / \mathrm{W} 2$ & $\ldots \ldots \ldots$ & $\mathrm{W} 2 / \mathrm{Wn}$ \\
\hline$\ldots \ldots$. & $\ldots \ldots \ldots$ & $\ldots \ldots \ldots$ & $\ldots \ldots \ldots$ & $\ldots \ldots \ldots$ \\
\hline Kriter $n$ & $\mathrm{Wn} / \mathrm{W} 1$ & $\mathrm{Wn} / \mathrm{W} 2$ & $\ldots \ldots \ldots$ & $\mathrm{Wn} / \mathrm{Wn}$ \\
\hline
\end{tabular}

Matematiksel olarak bu ilişki; wi / wj = aij (i,j =1, 2, ...n)

(wi: i.nci alternatifin ağırlığı wj: j.nci alternatifin ağırlı̆̆ı) ile ifade edilir. A ikili karşılaştırmalar matrisi, aşağıdaki gibi gösterilebilir.

$$
\mathrm{A}=\left[\begin{array}{ccccc}
1 & \ldots & a i j & \ldots & a m n \\
\ldots & 1 & & & \ldots \\
\frac{1}{a i j} & & 1 & & \ldots \\
\ldots & & & 1 & \ldots \\
\frac{1}{a m n} & \ldots & \ldots & \ldots & 1
\end{array}\right]
$$

\section{Adım 4: Öncelik Vektörünün Olușturulması}

Bu aşamada, öncelik veya ağırlık vektörlerinin hesaplanması için öncelikle ilişki matrisleri normalleştirilir. Normalleştirilmiş matris, her bir sütun değerinin ayrı ayrı ilgili sütun toplamına bölünmesi ile elde edilir. Daha sonra normalleştirilmiş matrisin satır değerlerinin ortalamasının alınması ile her bir kriter, alt kriter ve alternatifin ağırlıkları veya öncelik vektörü elde edilir.

\section{Adım 5: Tutarlılık Oranının Hesaplanması}

İkili karşılaştırmalar sonucunda oluşan değerlerin yani önceliklerin birbirleri ile olan mantıksal ve/veya matematiksel ilişkisi tutarlılıktır. AHP'nin modellemesi yapılırken, değerlendirmeye tabi tutulan alternatiflerin/kriterlerin göreceli önem düzeyleri bulunarak karşılaştırma matrisinin tutarlılığ hesaplanmalıdır. Bu matrisin tutarlı olabilmesi için en büyük öz değerin ( $\lambda \max$ ) matris boyutuna (n) eşit olması gerekmektedir.

Kriterlerin göreceli önemlerini hesaplamak için, her bir satırın ortalaması alınarak "sütun vektörü" oluşturulur. Oluşturulan sütun vektörü normalleştirilerek, "göreceli önemler vektörü” elde edilir. Matristeki her bir satır göreceli önem vektörüyle çarpılarak ağırlıklı önem vektörü elde edilir. Daha sonra bu vektörün her bir elemanı, göreceli önem vektöründe karşılık gelen elemana bölünerek bir başka vektör hesaplanır. Sonuç olarak bu vektörün aritmetik ortalaması ise en büyük öz değer olan " $\lambda$ max" ' 1 vermektedir. Daha sonra tutarlılık göstergesi ve oranı aşağıdaki gibi hesaplanarak sonucun doğruluğu kontrol edilir.

Tutarlılık göstergesi $(C I)=(\lambda \max -n) / n-1$

Tutarlılık Oranı (CR) = Tutarlılık göstergesi (CI) / Rassallık Göstergesi (RI)

Tutarlılık oranının hesaplanabilmesi için bir Rastgele Değer İndeks (R.İ.) Tablosu oluşturulmuştur. Boyutları 1 ile 15 arasında değişen kare matrisler için rastgele değer indeksi sayıları Tablo 4' de verilmiştir. $\mathrm{N}$ matris boyutuna göre rassal değerler görülmektedir. Burada n kriter sayısıdır ve bu sayı yani boyut büyüdükçe rassal gösterge değerlerinde de bir artış bulunmaktadır.

Tablo 4. Rastgele Değer İndeksi (R.I.) Tablosu

\begin{tabular}{|l|l|l|l|l|l|l|l|l|l|l|l|l|l|l|l|}
\hline $\mathbf{N}$ & $\mathbf{1}$ & $\mathbf{2}$ & $\mathbf{3}$ & $\mathbf{4}$ & $\mathbf{5}$ & $\mathbf{6}$ & $\mathbf{7}$ & $\mathbf{8}$ & $\mathbf{9}$ & $\mathbf{1 0}$ & $\mathbf{1 1}$ & $\mathbf{1 2}$ & $\mathbf{1 3}$ & $\mathbf{1 4}$ & $\mathbf{1 5}$ \\
\hline $\begin{array}{l}\text { Rasallık } \\
\text { Göstergesi }\end{array}$ & 0 & 0 & 0,58 & 0,9 & 1,12 & 1,24 & 1,32 & 1,41 & 1,45 & 1,49 & 1,51 & 1,48 & 1,56 & 1,57 & 1,59 \\
\hline
\end{tabular}


Karar matrisinin tutarlı olabilmesi için $\mathrm{CR}<0$, olması istenir. CR ne kadar sıfıra yakınsa karşılaştırma sonuçları daha tutarlı olacaktır. Bu belirlemelerin ardından karşılaştırmaların tutarlılık oranını sağlayıp sağlamadığı kontrol edilir. Sağlamaması durumunda karar vericiden kararını gözden geçirerek düzeltmesi istenir. Daha sonra ikili karşılaştırma matrislerinden göreli ağırlıklar hesaplanmaktadır. Son aşamada hiyerarşik yapı prensibi ile en alt seviyedeki alternatiflerin en üst seviyedeki genel amaca göre genel ağırlıkları elde edilmektedir.

\subsection{TOPSİS Yöntemi}

TOPSİS (Technique for Order Preference by Smilarity to Ideal Solution) yöntemi alternatif çözüm noktasının pozitif-ideal çözüme en kısa mesafe ve negatif-ideal çözüme en uzak mesafede olacağı varsayımına göre oluşturulmuştur.

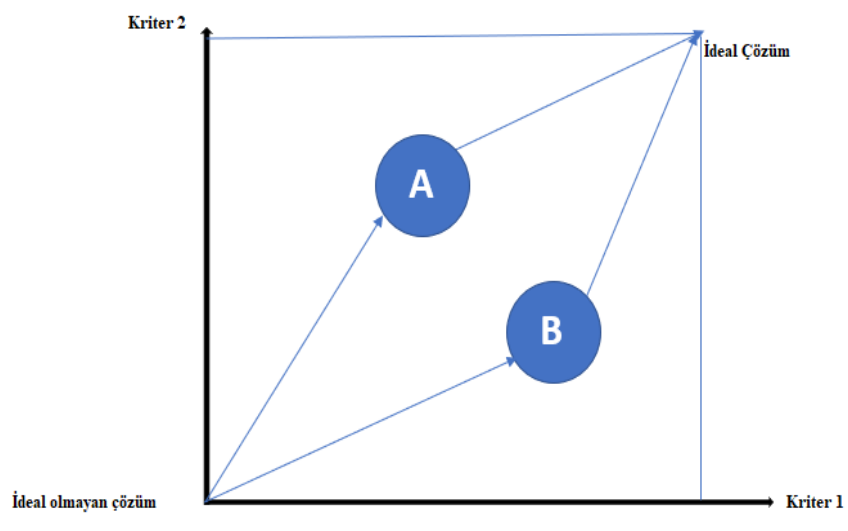

Şekil 4 .TOPSIS Model

\subsubsection{TOPSİS Aşamaları}

\section{Aşama: Karar Matrisinin (A) Oluşturulması}

$$
\mathrm{A}_{\mathrm{ij}}=\left[\begin{array}{cccc}
a_{11} & a_{12} & \ldots & a_{1 n} \\
a_{21} & a_{22} & \ldots & a_{21} \\
\ldots & \ldots & \ldots & \ldots \\
a_{m 1} & a_{m 2} & \ldots & a_{m n}
\end{array}\right]
$$

\section{Aşama: Karar Matrisinin (R) Normalleştirilmesi}

Karar matrisindeki her bir değerin bulunduğu sütundaki değerlerin kareleri toplamının kareköküne bölünerek matris normalize edilir.

$$
\begin{array}{rl}
\mathrm{r}_{\mathrm{ij}}=\frac{a_{i j}}{\sqrt{\sum_{k=1}^{m} a_{k j}^{2}}} \quad \mathrm{i}=1,2 \ldots \ldots \mathrm{m} & \mathrm{j}=1,2 \ldots \ldots \mathrm{n} \\
\mathrm{R}_{\mathrm{ij}} & =\left[\begin{array}{cccc}
r_{11} & r_{12} & \ldots & r_{1 n} \\
r_{21} & r_{22} & \ldots & r_{2 n} \\
\ldots & \ldots & \ldots & \ldots \\
r_{m 1} & r_{m 2} & \ldots & r_{m 2}
\end{array}\right]
\end{array}
$$

\section{Aşama: Normalleştirilen Karar Matrislerinin Ağırlıklandırılması (V)}

Öncelikle değerlendirme kriterlerine ilişkin ağırlık değerleri $\left(w_{i}\right)$ belirlenir. 


$$
\sum_{i=1}^{m} w_{i}=1
$$

Daha sonra R matrisinin her bir sütunundaki elemanlar ilgili wi değeri ile çarpılarak Ağırlıklı Standart Karar Matrisi (V) matrisi oluşturulur. V matrisi aşağıda gösterilmiştir:

$$
\mathrm{V}_{\mathrm{ij}}=\left[\begin{array}{cccc}
w_{1} r_{11} & w_{2} r_{12} & \ldots & w_{n} r_{1 n} \\
w_{1} r_{21} & w_{2} r_{22} & \ldots & w_{n} r_{2 n} \\
\ldots & \ldots & \ldots & \ldots \\
w_{1} r_{m 1} & w_{2} r_{m 2} & \ldots & w_{n} r_{m n}
\end{array}\right]
$$

Oluşturulacak ağırlıklı normalize edilmiş karar matrisi için, R matrisinin sütunlarındaki değerler ilgili değerlendirme kriteri ağırlık değerleri ile çarpılarak $\mathrm{V}$ matrisinin sütunları hesaplanmaktadır.

\section{Aşama: İdeal (A+) ve Negatif İdeal (A-) Çözümlerin Oluşturulması}

İdeal çözümün oluşturulabilmesi için ağırlıklı standart karar matrisindeki değerlendirme kriterlerinin yani sütun değerlerinin en büyükleri seçilir. İdeal çözüm setinin bulunması aşağıdaki formülde gösterilmiştir.

$\mathrm{A}^{+}=\left\{\left(\max v_{i j} \mid j \in \mathrm{J}\right),\left(\boldsymbol{m i n} \boldsymbol{v}_{\boldsymbol{i j}} \mid \boldsymbol{j} \in \mathrm{J}^{\prime}\right)\right\}$

Negatif ideal çözüm seti ise, ağırlıklı standart karar matrisindeki değerlendirme kriterlerinin yani sütun değerlerinin en küçükleri seçilerek oluşturulur. Negatif ideal çözüm setinin bulunması aşağıdaki formülde gösterilmiştir.

$\mathrm{A}^{-}=\left\{\left(\min v_{i j} \mid j \in \mathrm{J}\right),\left(\boldsymbol{m a x} v_{i j} \mid j \in \mathrm{J}^{\prime}\right)\right\}$

\section{Aşama: Ayrım Ölçütlerinin Hesaplanması}

TOPSİS yönteminde her bir karar noktasına ilişkin değerlendirme kriteri değerinin ideal ve negatif ideal çözüm setinden sapmalarının bulunabilmesi için Euclidian Uzaklık Yaklaşımından yararlanılmaktadır. Buradan elde edilen alternatiflere ilişkin sapma değerleri ise İdeal Ayırım $\left(\boldsymbol{S}_{\boldsymbol{i}}^{*}\right)$ ve Negatif İdeal Ayırım $\left(\boldsymbol{S}_{\boldsymbol{i}^{-}}\right)$Ölçütü olarak adlandırılmaktadır. İdeal ayırım $\left(\boldsymbol{S}_{\boldsymbol{i}}^{*}\right)$ ve negatif ideal ayırım $\left(\boldsymbol{S}_{\boldsymbol{i}}{ }^{-}\right)$ölçüleri aşağıdaki formüllere göre hesaplanmaktadır.

$S_{i}^{*}=\sqrt{\sum_{j=1}^{n}\left(v_{i j}-v_{j}^{-}\right)^{2}}$

$S_{i}^{-}=\sqrt{\sum_{j=1}^{n}\left(v_{i j}-v_{j}^{-}\right)^{2}}$

\section{Aşama: İdeal Çözüme Göre Göreli Çözümün Hesaplanması}

Her bir karar noktasının ideal çözüme göreli yakınlığının $\left(\mathrm{C}_{\mathrm{i}}{ }^{*}\right)$ hesaplanmasında ideal ve negatif ideal ayrım ölçütlerinden yararlanılmaktadır. Burada kullanılan ölçüt, negatif ideal ayrım ölçütünün toplam ayırım ölçütü içindeki payıdır. İdeal çözüme göreli yakınlık değerinin hesaplanması aşağıdaki formülde gösterilmiştir.

$$
\mathrm{C}_{\mathrm{i}}^{*}=
$$

$\frac{S_{i}^{-}}{\left(S_{i}^{-}-S_{i}^{*}\right)}$

\subsection{Uygulama}

\subsubsection{Alternatiflerin Belirlenmesi}

E-ticaret web siteleri, ticari işlemlerinin açıklamasına göre genellikle beş türe ayrılır: işletmeden işletmeye (B2B), işletmeden tüketiciye (B2C), tüketiciden tüketiciye (C2C), tüketici- işletmeye (C2B) ve işletmeden devlete (B2G).

Türkiye'de en çok site trafiğine sahip 50 web sitesi arasından müşteri odaklı perakende satış hizmeti veren 10 site Alexa.com tarafından sağlanan verilerle seçilmiştir. Alexa tarafından sağlanan veriler, Türkiye'de kullanılan yerel ve uluslararası web siteleridir.

İşletmeden tüketiciye (B2C), bu tür e-ticaret türleri arasında geleneksel fiziksel satış noktalarına bile rakip olan önemli bir perakende kanalı haline gelmiştir. Kuşkusuz, kurulan B2C eticaret web sitelerinin çoğu, sık sık artan satış hacimlerinden keyif almaktadır. Bu yenilikçi ticari paradigmanın dikkate değer ölçüde hızlandırılmış evrimi ve başarısı, müşterinin B2C e-ticaret web sitelerine olan sürekli memnuniyeti ve güveni ile ilgili temel sorun yapısını ortaya çıkarmaktadır. $\mathrm{Bu}$ nedenle; bu araştırmada, müşteri taleplerini daha iyi karşılamak için açıç̧a B2C e-ticaret web sitelerinin değerlendirilmesine odaklanılmıştır. (Kang, 2016).

Çalışmada kullanılan B2C odaklı web siteleri; Amazon, AliExpress, Apple, Udemy, Kitapseç ve Hepsiburada'dır.

Tüketiciden tüketiciye (C2C), müşteriler arasında çevrimiçi satın alma ayarlamalarının sosyal ve ticari hizmetlerini destekleyen bir e-ticaret iş modelidir. C2C modelleri, müşteri beklentisi, alıcının satıcıların başarısına yönelik algısından oluşturulduğunda, bu algı müşterilerin e-ticaret ürününü satın alma niyetini teşvik eder (Sukrat ve Papasratorn, 2018).

Çalışmada kullanılan C2C odaklı web siteleri; GittiGidiyor, Sahibinden, N11 ve Trendyol'dur. 
Sitede sadece 3 kişilik bir ekip, 6 kategori ve 2.700 ilan ile Sahibinden 2000 y1lında faaliyete geçmiş ve büyük ilgi görmüştür (Patronturk, 2012). Gittigidiyor 3 ortaklı bir şirket olarak kurulmuş ve 5 Şubat 2001'de hizmete girmiştir (Ertemel ve Çelik, 2016).

\section{Tablo 5. Web Siteleri}

\begin{tabular}{|l|c|}
\hline Websitesi & Trafik Yüzdesi \\
\hline Kitapsec.com & $\% 47,30$ \\
\hline Apple.com & $\% 37,30$ \\
\hline Hepsiburada.com & $\% 32,10$ \\
\hline Sahibinden.com & $\% 24,90$ \\
\hline GittiGidiyor.com & $\% 23,10$ \\
\hline Amozon.com.tr & $\% 22,70$ \\
\hline N11.com & $\% 21,60$ \\
\hline Trendyol.com & $\% 20,80$ \\
\hline Amozon.com & $\% 19,50$ \\
\hline Udemy.com & $\% 16,80$ \\
\hline Ali Express.com & $\% 14,40$ \\
\hline
\end{tabular}

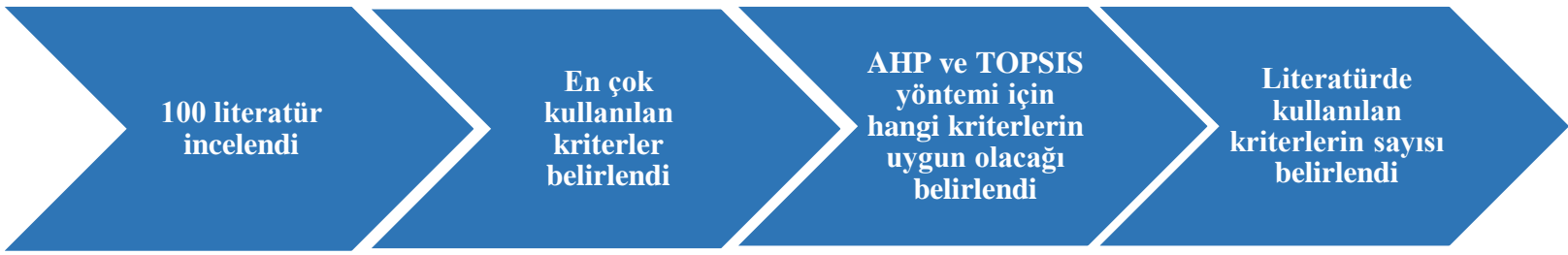

Şekil 5. Kriter Belirleme Süreci

İncelenilen literatürde belirtilen kriterlerin kullanım miktarı aşağıdaki Şekil 6'da verilmiştir.

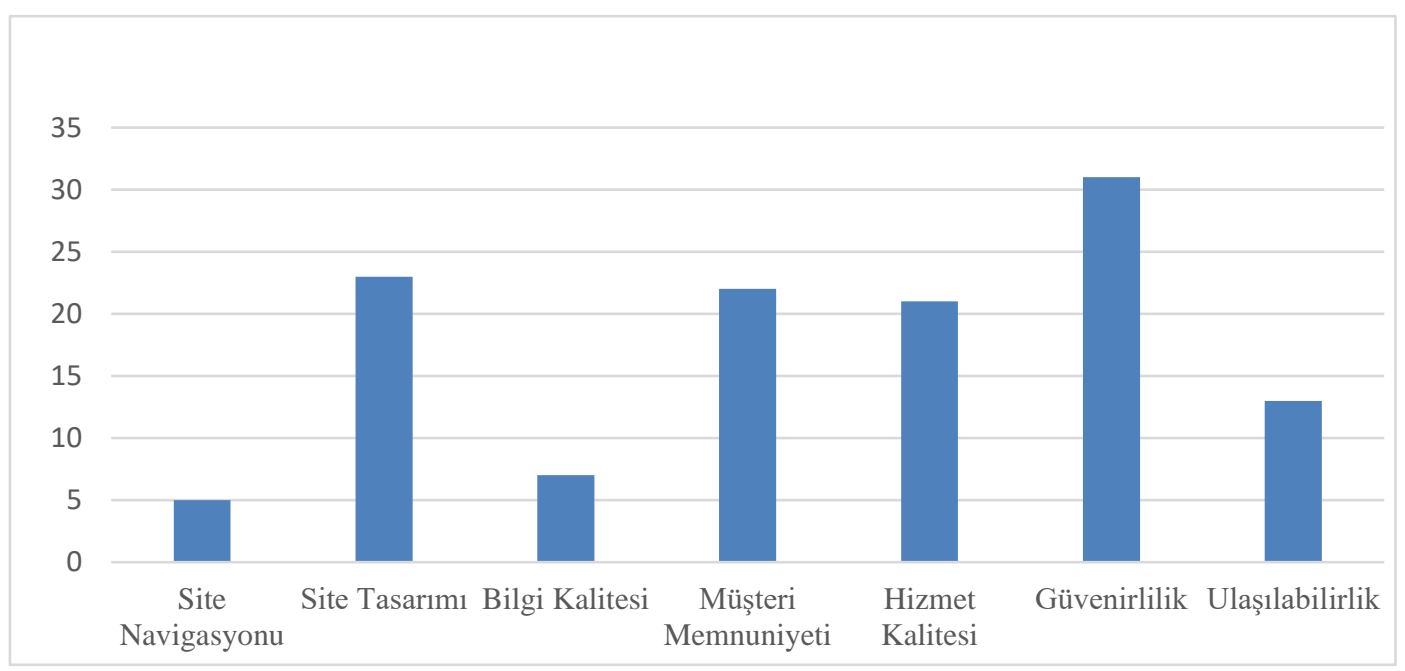

Şekil 6. Kriterlerin Literatürdeki Kullanım Miktarı

Belirtilen kriterlerin açıklaması aşağıdaki Tablo 7'de verilmiştir. 
Tablo 7. Kriterlerin Açıklaması

\begin{tabular}{|l|l|}
\hline Kriter & Açıklama \\
\hline Güvenilirlik & $\begin{array}{l}\text { Sitenin kurumsal kimliği müşteriler tarafından benimsenmekte ve site hizmet } \\
\text { güvenilirliği sağlamaktadır. }\end{array}$ \\
\hline Bilgi Kalitesi & $\begin{array}{l}\text { Fiyat bilgisi, ürün karşlaşı̧ıması, ürün açıklaması, ürün özellikleri, kullanıcı } \\
\text { deneyimleri gibi tanımları içerir. }\end{array}$ \\
\hline Ulaşılabilirlik & $\begin{array}{l}\text { Kullanıcı bilgilerini kullanmadan sitede gezinme ve site içerisinde hizmet } \\
\text { kolaylı̆̆ sağlama yeteneğidir. }\end{array}$ \\
\hline Site Tasarımı & $\begin{array}{l}\text { Site tasarımının açı, basit ve eğlenceli bir şekilde olmasıdır. Metin ve } \\
\text { görsellik gibi tasarım öğeleri müşteri işlemlerini kolaylaştırır. }\end{array}$ \\
\hline Site Navigasyonu & $\begin{array}{l}\text { Site yönlendirmesi anlaşılabilir olup doğru seçenekler sunarak sitede } \\
\text { gezinmeyi kolaylaştırır. }\end{array}$ \\
\hline Hizmet Kalitesi & $\begin{array}{l}\text { Müşserilerin ihtiyaç ve beklentilerine uygun turistik mal ve hizmet } \\
\text { özelliklerinin işletme tarafindan önceden belirlenmiş standartlara sürekli ve } \\
\text { tutarlı şekilde uyumlu olmasıdır. }\end{array}$ \\
\hline Müşteri Memnuniyeti & Satı̧ öncesi ve satış sonrası hizmetlerdir. \\
\hline
\end{tabular}

(Adıgüzel,2010) tüketicilerin çevrimiçi alıșveriș davranışları ile alışveriş yaptıkları sanal mağazaların atmosferi arasındaki ilişkiyi açıklamak için bir model geliştirmiştir. (Armağan ve Turan 2014), tüketicilerin internetten alışveriş yapmamasının nedenlerini, alışveriş yapanların en çok satın aldıkları ürün ve hizmetleri ve internetten alışveriş yapmanın faydalarını araştırmıştır. (Aydın ve Derer ,2015) demografik değişkenler ile internetten alışveriş yapan ve yapmayan tüketicilerin satın alma davranışları arasında bir ilişki olup olmadığını araştırmıştır. (Aksoy ve Sever,2012) internet kullanıcılarının sayısının gün geçtikçe arttığını, ancak çoğu kullanıcının çevrimiçi alışverişe güvenmedikleri için kişisel bilgilerini web siteleriyle paylaşma konusunda isteksiz olduklarını bulmuştur. (Cesur ve Tayfur ,2015) çevrimiçi alışveriş davranışında algılanan tüketici risklerini belirlemek için üniversite öğrencileri üzerinde bir araştırma yapmıştır. (Çetin ,2014) akademisyenlerin internet alışverişindeki davranışlarını ve onları alışverişe yönlendiren faktörleri belirlemiştir. (Doğrul ,2012) tüketicilerin alışveriş davranışını etkileyen nedenleri belirlemiş ve elektronik alışveriş ortamında yapılan alışverişleri faydacı ve hedonik motifler açısından değerlendirmiştir.

(Durmus ve Tayyar ,2017) AHP ve TOPSİS yönteminde en iyi üç alternatif siteyi kullanarak güvenilirlik, gizlilik, ödeme kolaylığı ürünleri ile web sitesi performansı ile bilgi ve çeşitliliğe dayalı dört kriter de dahil olmak üzere Türkiye'deki en iyi online alışveriş sitelerini belirlemişlerdir. (Dulkadir ve Akkoyun,2013) Malatya'da faaliyet gösteren tekstil firmaları kapsamında elektronik ticaret kullanan işletmelerin kendi işletmeleri ve işletme dışı üzerindeki etkilerini araştırmışlardır. (Durmaz vd.,2015), gelişen internet teknolojileri ve satış noktaları ile değişen çevrimiçi pazarlama hakkında bilgiler ortaya koymuştur. (Hayran vd.,2017) Türkiye'de internetten alışveriş yapan bireylerin risk algısını cinsiyet farklılıkları açısından değerlendirilmiştir. (Gümül ,2015) algılanan faydaların, tüketici deneyiminin ve satış promosyonlarının tüketicilerin çevrimiçi alışveriş davranışlarını önemli ölçüde etkilediğini bulmuştur. (İşler vd.,2014) çevrimiçi ürün satın alan tüketicilerin davranışlarını etkileyen faktörleri, bu faktörlere yönelik gelişen tutumları ve bu tutumların demografik değişkenlerle ilişkisini araştırmıştır. (Spectrum ve Falcon,2013) Türkiye'de elektronik perakende sektörünü, internet üzerinden alışveriş yapan tüketicilerin profilini ve internet yapısını belirleme nedenlerimi açıklamayı tercih edip etmediklerini belirlemiştir. (Kızılaslan ve Ünal,2015) firsatları, firsatları, tehditleri, eksiklikleri ve eticaretin tarım sektörüne katkısını araştırmışlardır. (Karlıdağ ve Bulut,2015) e-alışveriş sitelerinin tüketicilerin kişisel bilgilerini korumak için hangi politikaları uyguladığını analiz etmiştir. (Mürütsoy ,2013) akademik ve idari personel ile yaptığı anketle yaş, gelir dağılımı, cinsiyet, eğitim durumu, internette önceki satın alma deneyimleri ve bilgi düzeyleri gibi konuların tüketici davranışını nasıl etkilediğini belirlemeye çalışmıştır. (Sertoğlu vd.,2017) tüketicilerin e-alışveriş davranışlarını belirlemiş ve satın alma karar sürecinin hangi aşamasında internetin daha yoğun kullanıldığını belirlemiştir. (Oskaybaş vd.,2014) hazır giyim sektöründe tüketicilerin sanal mağaza tercihlerini belirleyen faktörleri belirlemiştir.

(K1lıç,2015) elektronik ticaretin hem tüketici hem de işletme açısından faydalarına vurgu yaparak, tüketicilerin elektronik ticaret yoluyla alışveriş yapmaktan kaçınmasının dezavantajlarını ve nedenlerini vurguladı. (Sayılı ve Büyükköroğlu,2012) Tokat'ta yaşayan tüketicilerin e-ticaret yoluyla gıda ürünleri satın almaya yönelik tutumlarını etkileyen sosyo-ekonomik faktörleri incelemiştir.

(Şimşek,2016) e-ticaret sitelerinin güvenilirliğini, banka çalışanlarının internet ortamına olan güvenini ve online alışverişi tercih eden banka çalışanlarının risk eğilimlerini; banka çalışanlarının e-ticarete güven tutumları arasında anlamlı bir fark olup olmadığı araştırmıştır. (Terzi ve Mandal,2016) perakende sektöründe faaliyet gösteren firmaların e-ticaret ve e-lojistik bağlamında güçlü ve zayıf yönlerini, tehditlerini ve firsatlarını ortaya koymuştur. (Üster,2015) internetten alışveriş yapan tüketicilerin kontrolsüz satın alma eğilimlerini incelemiştir.

(Yılmaz ve Tümtürk ,2015) internetten alışveriş yapan tüketicilerin niyetini etkileyen faktörleri belirlemek için Teknoloji Kabul Modeli ve Yapısal Eşitlik Modelini kullanmıştır. (Yılmaz vd.,2016) çevrimiçi alışverişte müşteri şikayet niyet ve davranışlarını yapısal eşitlik modeli kullanarak incelemiştir. (Yalçın ,2012) müşterilerin online alışverişteki davranışlarını ve özellikle günün firsatından duydukları memnuniyeti araştırmıştır. 
(Yavuz ve Gov ,2015) farklı demografik özelliklere sahip tüketicilerin elektronik ticarete yönelik algılarını belirlemiştir

\subsection{Veri Toplama}

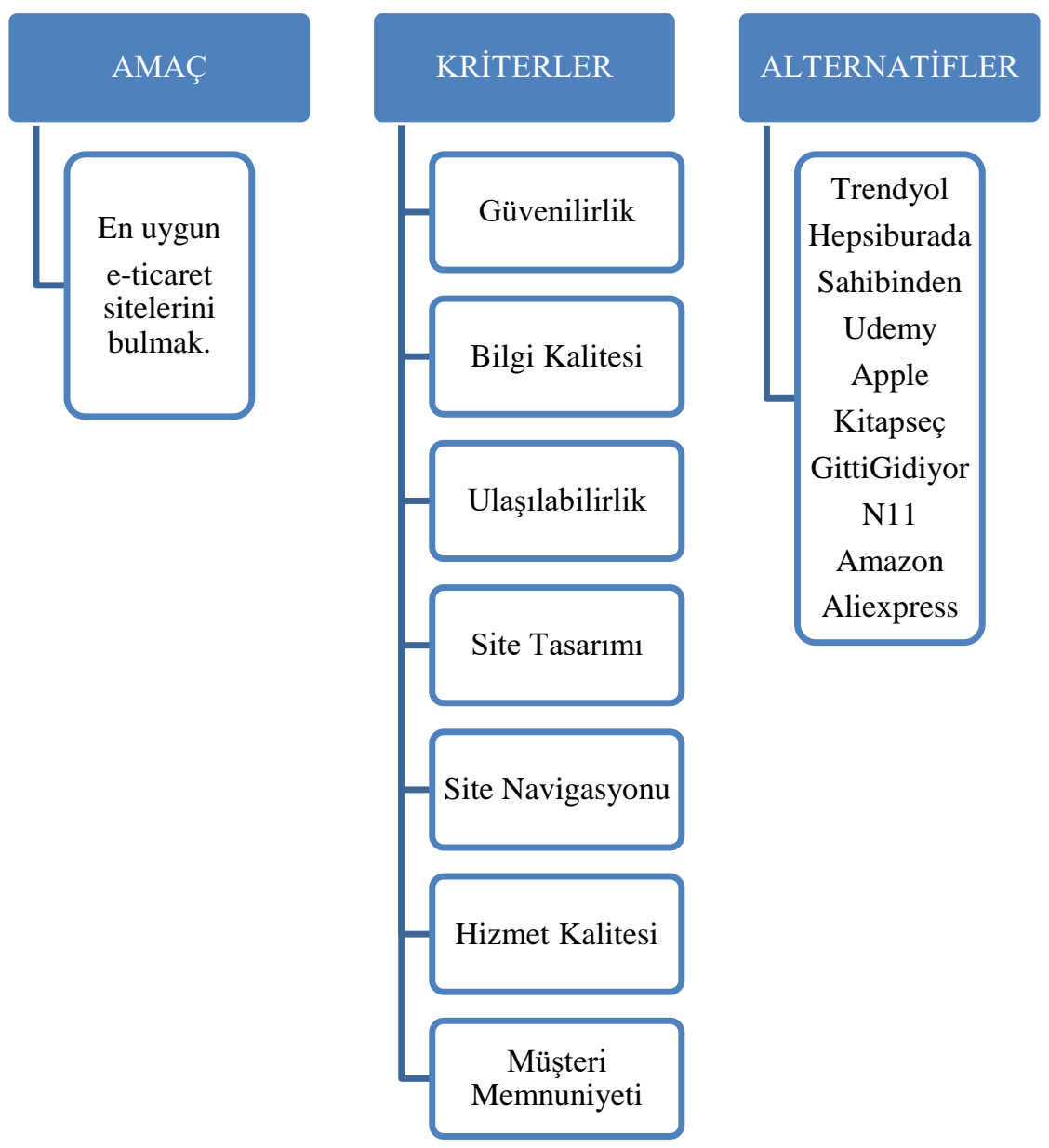

Şekil 7. Modelin Amacl

Şekil 7 çalışmanın genel amacının gösterimidir. Online alışveriş sağlayan en uygun e-ticaret sitesini seçmek için 7 kriter belirlenmiştir. Bu kriterler; sitede navigasyonu, site tasarımı, bilgi kalitesi, müşteri memnuniyeti, hizmet kalitesi, güvenilirlik, ulaşılabilirliktir. Kriterleri bütünsel bir yaklaşımla değerlendirildi ve ardından her bir kriterin önemini AHP ve TOPSISS yöntemleriyle belirlendi ve bu model ile belirlenen her e-ticaret sitesinin kullanılabilirlik puanlarını analiz edilmiştir.

Uygulamanın temel amac1, uluslararası site analizi yapan Alexa verilerine göre site trafik yoğunluğu açısından 10 siteyi belirleyerek e-ticaret alışveriş sitelerinin kullanıcı arayüzünün kullanılabilirliğini değerlendirmektir. Bu kapsamda belirlenen alanlar için literatürdeki önemli kriterler araştırılmış, her bir kriteri ölçmek için sorular hazırlanmış ve anketler oluşturulmuştur.
Araştırmada AHP ve TOPSİS yöntemi kullanılacağından, kriterlerin daha hassas değerlendirilmesi çalışılmış ve 10 e-ticaret sitesi için 10 farklı anket oluşturulmuştur. Her anket, 8 tane demografik, 13 tane kullanıcıların çevrimiçi alışveriş alışkanlıklarını değerlendiren toplam 21 sorudan oluşmaktadır.

Anket soruları beşli likert ölçeğine göre hazırlanmıştır. Online bir platformda oluşturulan anketler sonuçlandırıldıktan sonra eticaret uzmanı 4 mühendis tarafından değerlendirildikten sonra veri toplama süreci online olarak ilgili kullanıcılara gönderilerek başlatılmıştır.

Veri toplama sürecinde sosyal medya platformlarından destek alınarak toplam 366 kişiye ulaşılmıştır. Ankete başlamadan önce kullanıcılara rehberlik eden bölümler kullanılarak kullanıcıların deneyimleri ölçülmüştür. 


\begin{tabular}{|c|c|}
\hline Kriterler & Anket Soruları \\
\hline Site Navigasyonu & $\begin{array}{l}\text { Alışveriş yaparken alacağım ürünle ilgili sitenin beni doğru ürüne } \\
\text { yönlendirmesini beklerim (Childers vd, 2001). }\end{array}$ \\
\hline Site Tasarımı & $\begin{array}{l}\text { Site tasarımının iyi olması (site ana sayfa görselliği, yönlendirme tuşları } \\
\text { gibi) online alısverişte tercih sebebimdir (Enginkaya, 2006). }\end{array}$ \\
\hline Bilgi Kalitesi & $\begin{array}{l}\text { Alışveriş yaptı̆̆ım e-ticaret sitesinin ürün görsellerinden çok ürünler } \\
\text { hakkında detaylı açıklamalar yapması daha önemlidir (Ahuja vd., 2003). }\end{array}$ \\
\hline Müşteri Memnuniyeti & $\begin{array}{l}\text { Alışveriş yaptığım e-ticaret sitesinin satış öncesi ve sonrası hizmet kalitesi } \\
\text { site seçimimi etkilemektedir (Kurt ve Hacığlu, 2008). }\end{array}$ \\
\hline Hizmet Kalitesi & $\begin{array}{l}\text { Alışveriş yaptığım sitenin dijital bir yardımcı (yardımcı düğme) olması o } \\
\text { siteyi tercih etme sebebidir (Ahn vd., 2007; Santouridis vd., 2009). }\end{array}$ \\
\hline Güvenilirlik & $\begin{array}{l}\text { Çevremdeki pek çok kişinin benzer sitelerden alışveriş yapması o sitenin } \\
\text { güvenilirliğini göstermektedir (Menon,2018; Algür,2011; Keaveney, 2001; } \\
\text { Monsuwé, 2004). }\end{array}$ \\
\hline Ulaşılabilirlik & $\begin{array}{l}\text { Siteye giriş yaptı̆̆ımda üyelik istemeden ürüne bakıp sepete ekleyebilmem } \\
\text { siteyi tercih sebebimdir (Reibstein, 2002). }\end{array}$ \\
\hline
\end{tabular}

\section{Araştırma Sonuçları ve Tartışma}

\subsection{Demografik Analiz}

Araştırmaya katılanların \%73,22'si kadın, \%26,78'i erkektir. Elde edilen bulguya göre, anketi cevaplayanların büyük bir kısmı kadındır. Cevaplayanların yaş gruplarına göre dağılımı şöyledir; 18-25 yaş grubu, katılanların \%66,12'sini, 26-35 yaş grubu, $\% 19$,13'ünü, 36-45 yaş grubu, \%9,30'unu, 46- 55 yaş grubu, 4,64'ünüve son olarak 55 yaş üstü ise $\% 0,81$ 'ini oluşturmaktadır. Bu bulgulara göre, cevaplayanların çoğu 18-25 yaş grubunda ve genç kişilerdir. Anketi cevaplayanların \%2,18'i ilkokul mezunu, $\% 12,30$ 'u lise mezunu, \%73,22'si lisans mezunu ve \%12,30’u lisansüstü mezunu kişilerden oluşmaktadır. Elde edilen bulguya göre cevaplayanların çoğu lisans mezunu kişilerdir. Bu durum, cevaplayan kişilerin eğitim düzeylerinin yüksek olduğunu göstermektedir. Anketi cevaplayanların \%39,90'1 0-1000, \%20,70'i 1000-3000, \%23'ü 3000-5000, \%16,40'1 5000- den fazla gelir grubunda olan kişilerden oluşmaktadır. Elde edilen bu bulgu ankete katılanların çoğunun 0-1000 gelir aralığında olduğunu göstermektedir. Cevaplayıcılar genel olarak düşük gelir grubunda olan kişilerdir. Anketi cevaplayanların online alışverişi yaptıkları platform, \%20'si websitesi, \%32'si mobil uygulama, \%48'i her iki platformdan yapmaktadır. Elde edilen bulguya göre, katılımcıların online alışverişi her iki platformdan yaptı̆̆ını göstermektedir. 
Avrupa Bilim ve Teknoloji Dergisi

Tablo 9. Anket Katılımcllarının Profili

\begin{tabular}{|c|c|c|c|c|c|}
\hline Cinsiyet & $\bar{s}$ & $\%$ & Gelir Düzeyi & $\bar{s}$ & $\%$ \\
\hline Kadın & 268 & $73,22 \%$ & $0-1000$ & 146 & $39,90 \%$ \\
\hline Erkek & 98 & $26,78 \%$ & $1000-3000$ & 76 & $20,70 \%$ \\
\hline Toplam & 366 & $100,00 \%$ & $3000-5000$ & 84 & $23,00 \%$ \\
\hline Yaş & $\bar{s}$ & $\%$ & $5000+$ & 60 & $16,40 \%$ \\
\hline $18-25$ & 242 & $66,12 \%$ & Toplam & 366 & $100,00 \%$ \\
\hline $26-35$ & 70 & $19,13 \%$ & $\begin{array}{l}\text { Çevrimiçi Alışveriş } \\
\text { Platformu }\end{array}$ & $\mathrm{s}$ & $\%$ \\
\hline $36-45$ & 34 & $9,30 \%$ & Website & 73 & $20,00 \%$ \\
\hline $46-55$ & 17 & $4,64 \%$ & Mobil uygulama & 117 & $32,00 \%$ \\
\hline $55+$ & 3 & $0,81 \%$ & Her iki platform & 176 & $48,00 \%$ \\
\hline Toplam & 366 & $100,00 \%$ & Toplam & 366 & $100,00 \%$ \\
\hline Ĕgitim & $\mathrm{s}$ & $\%$ & & & \\
\hline İlkokul & 8 & $2,18 \%$ & & & \\
\hline Lise & 45 & $12,30 \%$ & & & \\
\hline Lisans & 268 & $73,22 \%$ & & & \\
\hline Lisansüstü & 45 & $12,30 \%$ & & & \\
\hline Toplam & 366 & $100,00 \%$ & & & \\
\hline
\end{tabular}

\subsection{AHP Metodu Uygulama Aşamaları}

Çevrimiçi alışveriş imkânı sağlayan 10 e-ticaret sitesi 7 farklı kriter ile kullanılabilirliliği değerlendirilmiştir. Değerlendirme yöntemlerinden AHP tarafından tanımlanan probleme göre sırasıyla AHP adımları takip edilmiştir. Tablo 10'da çalışmada kullanılan kriterlerin kodları verilmiştir.
Tablo 10. Kriterlerin Kodları

\begin{tabular}{|l|}
\hline K1: Güvenirlilik \\
\hline K2: Bilgi Kalitesi \\
\hline K3: Erişim \\
\hline K4: Site Tasarımı \\
\hline K5: Site Navigasyonu \\
\hline K6: Hizmet Kalitesi \\
\hline K7: Müşteri Memnuniyeti \\
\hline
\end{tabular}

AHP yöntemiyle 7 kriter ikili karşılaştırmalar yapılarak değerlendirilip kriterlerin önem dereceleri belirlenilmiştir. Ms Excel formatında oluşturulan Tablo 11'de kriterlerin ağırlıkları hesaplanılmıştır. 
European Journal of Science and Technology

Tablo 11. Kriterlerin İkili Karşılaştırma Matrisi

\begin{tabular}{|l|l|l|l|l|l|l|l|l|}
\hline & K1 & K2 & K3 & K4 & K5 & K6 & K7 & $\begin{array}{l}\text { Kriter } \\
\text { Ağırlı̆ı }\end{array}$ \\
\hline K1 & $\mathbf{1 , 0 0}$ & 7,00 & 3,00 & 3,00 & 0,33 & 0,20 & 0,20 & 0,12 \\
\hline K2 & 0,14 & $\mathbf{1 , 0 0}$ & 0,33 & 0,14 & 0,20 & 0,33 & 0,20 & 0,03 \\
\hline K3 & 0,33 & 3,00 & $\mathbf{1 , 0 0}$ & 5,00 & 0,14 & 0,20 & 0,33 & 0,09 \\
\hline K4 & 0,33 & 7,00 & 0,20 & $\mathbf{1 , 0 0}$ & 0,50 & 5,00 & 0,33 & 0,14 \\
\hline K5 & 3,00 & 5,00 & 7,00 & 2,00 & $\mathbf{1 , 0 0}$ & 3,00 & 2,00 & 0,27 \\
\hline K6 & 5,00 & 3,00 & 5,00 & 0,20 & 0,33 & $\mathbf{1 , 0 0}$ & 0,33 & 0,14 \\
\hline K7 & 5,00 & 5,00 & 3,00 & 3,00 & 0,50 & 3,00 & $\mathbf{1 , 0 0}$ & 0,21 \\
\hline
\end{tabular}

$\mathrm{Bu}$ ikili karşılaştırmaya göre, e-ticaret sitelerini değerlendirmek için hangi kriterin daha yüksek öneme sahip olduğunun belirlenilmesi amaçlanmaktadır. İkili karşılaştırma matrisindeki köșegen elemanların değerlerinin belirlenmesinde, herhangi bir alternatifin kendisi ile karşılaştırılmasında verilecek yargının "eşit derecede tercih edildiği" göz önünde bulundurulmuştur.

E-ticaret sitesi tasarımı konusunda uzman ve bu alanda çalışmış kişilerin bireysel görüşlerine göre ve çalışmada kullanılan anket sonuçlarına göre analizler yapılmıştır. Bu karşılaştırma matrisine göre alışveriş sitesi seçiminde en önemli kriter 0.27 ağırlığındaki site navigasyonu kriteri olarak belirlenmiştir. Bunu müşteri memnuniyeti, hizmet kalitesi, site tasarımı, güvenilirlik, sitelerin erişim kriterleri takip etmektedir. En az önemli kriter 0,03 puanla bilgi kalitesidir. $\mathrm{Bu}$ ikili karşılaştırma matrisinin tutarlılık oranı hesaplanmış olup, 0.07 değeri 0.1'den küçük bulunmuştur. $\mathrm{Bu}$, yapılan kriter analizinin tutarlı olduğunu göstermektedir.

Alternatif olarak tanımlanan e-ticaret sitelerinin değerlendirme matrisi oluşturulmuş ve kriterler bazında karşılaştırılmıştır. Sonuçlar Tablo 12'de verilmiştir.

Tablo 12. Alternatiflerin İkili Karşılaştırma Matrisi

\begin{tabular}{|l|l|l|l|l|l|l|l|}
\hline & K1 & K2 & K3 & K4 & K5 & K6 & K7 \\
\hline \hline Trendyol & 0,08 & 0,11 & 0,1 & 0,14 & 0,19 & 0,04 & 0,08 \\
\hline Amazon & 0,05 & 0,05 & 0,05 & 0,06 & 0,02 & 0,07 & 0,05 \\
\hline AliExpress & 0,05 & 0,04 & 0,05 & 0,12 & 0,05 & 0,02 & 0,04 \\
\hline Kitapsec & 0,09 & 0,08 & 0,07 & 0,02 & 0,03 & 0,02 & 0,07 \\
\hline Hepsiburada.com & 0,17 & 0,14 & 0,2 & 0,12 & 0,24 & 0,11 & 0,19 \\
\hline N11 & 0,26 & 0,25 & 0,21 & 0,23 & 0,17 & 0,18 & 0,28 \\
\hline Apple & 0,03 & 0,03 & 0,03 & 0,01 & 0,03 & 0,05 & 0,02 \\
\hline Sahibinden.com & 0,03 & 0,04 & 0,04 & 0,06 & 0,02 & 0,03 & 0,03 \\
\hline Udemy & 0,11 & 0,11 & 0,12 & 0,04 & 0,17 & 0,32 & 0,1 \\
\hline GittiGidiyor & 0,13 & 0,16 & 0,12 & 0,21 & 0,09 & 0,17 & 0,15 \\
\hline
\end{tabular}

AHP yöntemine göre, alternatifler kriterler bazında değerlendirilerek hangi alternatifin hangi kriterde en iyi olduğu belirlendi. Karşılaştırmaya göre, Trendyol sitesi, 7 kriterden en yüksek puanı site navigasyonundan almıştır. Site navigasyonu 
kriterinde en yüksek puanı alan site Hepsiburada olurken Amazon ve Sahibinden bu kriterde diğer sitelere göre daha düşük performanslı olarak değerlendirildi. Amazon, hizmet kalitesi ve site tasarımı açısından yüksek performans elde etmiştir. AliExpress, site tasarım kriterinde yüksek puan elde etmiş ve diğer kriterlerde yaklaşık olarak aynı performansa sahip olmuştur. Hizmet kalitesi kriterinde diğer sitelere göre daha düşük puan almıştır.

Hepsiburada.com sitesi, belirtilen kriterler ve karşılaştırıldığ diğer sitelere göre daha yüksek puana sahip, sadece hizmet kalitesi açısından daha düşük performanslı olarak değerlendirilmiştir. Apple'ın hizmet kalitesi, diğer kriterlere göre daha yüksek puanlı olarak değerlendirilmiş ve kriterlere göre değerlendirmede genellikle rakiplerinden daha düşük puan almıştır. Udemy, hizmet kalitesi kriterlerinde rakip sitelere göre en yüksek puanı alırken, site tasarımında düşük performanslı olarak değerlendirilmiştir. Sahibinden ve GittiGidiyor site tasarımda diğer kriterlere göre daha yüksek puan alırken, site navigasyonu kriterlerinde düşük bir puana sahip olmuştur.

Çapraz karşılaştırmalardan sonra tüm kriterler bazında sitelerinin kullanılabilirliğin sonuçları Tablo 13'de verilmiştir.
Tablo 13. AHP Metodu Sonuçları

\begin{tabular}{|l|l|}
\hline N11 & 0,19 \\
\hline Hepsiburada.com & 0,17 \\
\hline Udemy & 0,14 \\
\hline GittiGidiyor & 0,14 \\
\hline Trendyol & 0,11 \\
\hline AliExpress & 0,05 \\
\hline Kitapseç & 0,04 \\
\hline Amazon.com.tr & 0,04 \\
\hline Sahibinden & 0,03 \\
\hline Apple & 0,02 \\
\hline
\end{tabular}

AHP yöntemine göre en yüksek kullanılabilirlik puanına sahip olan Site N11; en düşük puana sahip site Apple'dır. Udemy ve GittiGidiyor siteleri değerlendirmeye göre yüksek puanlarla yakın bir performans sergilemektedir.

\subsection{TOPSís Metodu Uygulama Aşamaları}

Çalışmada kullanılan TOPSİS metmodu, e-ticaret sitelerinin kullanılabilirliğini değerlendirmek amacıyla uygulanılmış olan diğer karar verme yöntemidir. Aşağıda TOPSİS yöntemin uygulanışı verilmiştir.

Topsis'in ilk aşaması olan karar verme matrisi AHP metodundaki gibi oluşturulmuştur.Tablo 14'de verilmiştir.

Tablo 14. Kriterlerin Karar Verme Matrisi

\begin{tabular}{|l|l|l|l|l|l|l|l|}
\hline & K1 & K2 & K3 & C4 & C5 & C6 & C7 \\
\hline Trendyol & 4 & 5 & 5 & 5 & 6 & 3 & 6 \\
\hline Amazon & 3 & 4 & 3 & 3 & 2 & 6 & 5 \\
\hline AliExpress & 3 & 3 & 3 & 4 & 4 & 2 & 4 \\
\hline Kitapseç & 4 & 4 & 4 & 2 & 3 & 2 & 5 \\
\hline Hepsiburada & 6 & 6 & 7 & 4 & 7 & 6 & 7 \\
\hline N11 & 7 & 8 & 7 & 7 & 6 & 7 & 8 \\
\hline Apple & 2 & 2 & 2 & 2 & 3 & 5 & 2 \\
\hline Sahibinden & 2 & 3 & 3 & 3 & 2 & 3 & 3 \\
\hline Udemy & 5 & 5 & 6 & 3 & 6 & 8 & 6 \\
\hline GittiGidiyor & 5 & 7 & 6 & 6 & 5 & 7 & 7 \\
\hline
\end{tabular}

Karar matrisi belirlendikten sonra karar matrisinin normalleştirilmesi gerçekleştirilir. Karar matrisi için normalizasyon değerleri Tablo 15 'de gösterilmektedir.

Tablo 15. Karar Matrisinin Normalleştirme Dĕgerleri

\begin{tabular}{|l|l|l|l|l|l|l|l|}
\hline & K1 & K2 & K3 & K4 & K5 & K6 & K7 \\
\hline Trendyol & 0,2879 & 0,3143 & 0,3214 & 0,3758 & 0,4009 & 0,178 & 0,34 \\
\hline Amazon & 0,2159 & 0,2515 & 0,1928 & 0,2255 & 0,1336 & 0,355 & 0,28 \\
\hline AliExpress & 0,2159 & 0,1886 & 0,1928 & 0,3007 & 0,2673 & 0,118 & 0,23 \\
\hline Kitapseç & 0,2879 & 0,2515 & 0,2571 & 0,1503 & 0,2004 & 0,118 & 0,28 \\
\hline Hepsiburada & 0,4318 & 0,3772 & 0,45 & 0,3007 & 0,4677 & 0,355 & 0,4 \\
\hline N11 & 0,5038 & 0,503 & 0,45 & 0,5262 & 0,4009 & 0,415 & 0,45 \\
\hline Apple & 0,1439 & 0,1257 & 0,1286 & 0,1503 & 0,2004 & 0,296 & 0,11 \\
\hline
\end{tabular}




\begin{tabular}{|l|l|l|l|l|l|l|l|}
\hline Sahibinden & 0,1439 & 0,1886 & 0,1928 & 0,2255 & 0,1336 & 0,178 & 0,17 \\
\hline Udemy & 0,3599 & 0,3143 & 0,3857 & 0,2255 & 0,4009 & 0,474 & 0,34 \\
\hline GittiGidiyor & 0,3599 & 0,4401 & 0,3857 & 0,451 & 0,3341 & 0,415 & 0,4 \\
\hline
\end{tabular}

Karar matrisinin normalizasyon değerleri belirlendikten sonra, çalışmada analiz dönemi için kullanılan kriterler ve bu kriterlere verilen ağırlık değerleri Tablo 16 'da gösterilmiş̧ir. Kriterler belirlenen değerlere göre ağırlıklandırılır.

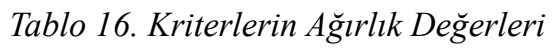

\begin{tabular}{|l|c|}
\hline \multicolumn{1}{|c|}{ Kriterler } & A ğırlık Vektörü \\
\hline Güvenirlilik & 0,12 \\
\hline Bilgi Kalitesi & 0,03 \\
\hline Ulaşılabilirlilik & 0,09 \\
\hline Site Tasarımı & 0,14 \\
\hline Site Navigasyonu & 0,27 \\
\hline Hizmet Kalitesi & 0,14 \\
\hline Müşteri Memnuniyeti & 0,21 \\
\hline
\end{tabular}

Daha sonra kriterlere verilen anlamlılık düzeylerine göre normalize edilmiş matris çarpımı yapılarak ağırlıklı matris elde edilir.

Ağırlıklı "D" matrisinde amaca göre $\mathrm{V} *$ ve $\mathrm{V}$ - (maksimum ve minimum) değerleri belirlenmiş, $\mathrm{S} *$ ve $\mathrm{S}$ değerleri kullanılarak performans puanları ve sıralamaları belirlenmiştir.

\section{Tablo 17. Sitelerin "D" Ağırlıklandırma Matrisi ile Ideal} Verilerin Belirlenmesi

\begin{tabular}{|l|l|l|}
\hline & \multicolumn{1}{|c|}{$V^{*}$} & \multicolumn{1}{|c|}{$V^{-}$} \\
\hline Trendyol & 0,5442 & 0,0837 \\
\hline Amazon & 0,5607 & 0,0355 \\
\hline AliExpress & 0,5583 & 0,0497 \\
\hline Kitapseç & 0,5523 & 0,0425 \\
\hline Hepsiburada & 0,5253 & 0,1069 \\
\hline N11 & 0,5157 & 0,0965 \\
\hline Apple & 0,1209 & 0,5597 \\
\hline Sahibinden & 0,5725 & 0,0322 \\
\hline Udemy & 0,5352 & 0,0873 \\
\hline GittiGidiyor & 0,5342 & 0,0741 \\
\hline
\end{tabular}

Yapılan aşamalara göre sitelerin kullanabilirlik puanları (S değerleri) Tablo 18'deki gibidir.

Tablo 18. E-ticaret Sitelerinin Stralamast ve Hesaplanan Performans Puanlart

\begin{tabular}{|l|l|}
\hline & S değerleri \\
\hline Sahibinden & 1,5725 \\
\hline Amazon & 1,5607 \\
\hline AliExpress & 1,5583 \\
\hline Kitapseç & 1,5523 \\
\hline Trendyol & 1,5442 \\
\hline Udemy & 1,5352 \\
\hline GittiGidiyor & 1,5342 \\
\hline
\end{tabular}

\begin{tabular}{|l|l|} 
Hepsiburada & 1,5253 \\
\hline N11 & 1,5157 \\
\hline Apple & 1,1209 \\
\hline
\end{tabular}

Tablo 18'e göre en iyi site performansı Sahibinden e-ticaret sitesi gösterirken, bu sırayı Amazon ve Aliexpress izlemiştir. Apple sitesi diğer alternatiflere göre daha düşük performanslı bulunmuştur.

Uygulanan AHP ve Topsis yöntemine göre farklı bulgular elde edinilmiştir. AHP metoduna göre 7 kriterden en çok önem verilen kriterler, site navigasyonu ve müşteri memnuniyetidir. Site kullanılabilirliği performansında ise Apple her iki yöntem de de düşük puan almıştır. Amazon sitesi TOPSİS de yüksek puan alırken AHP de aynı performansı göstermemiştir. Udemy, GittiGidiyor, Trendyol siteleri iki yöntem de benzer sonuçlar elde etmiştir.

\section{Sonuç}

Online alışverişi tercih eden tüketiciler, en iyi e-ticaret sitesini belirlemek istemektedir. E-ticaret siteleri ise kullanıc kullanılabilirliğini müşterilerinin beklentilerine göre üst seviyeye getirmek istemektedir. Belirlenen bu amaçlar doğrultusunda eticaret sitelerinin kullanılabilirliğinde hangi kriterlerin performansı etkilediğini belirleyebilmek ve en iyi e-ticaret sitesini seçebilmek için çoklu karar verme yöntemlerinden AHP ve TOPSİS ile siteler değerlendirilmiş ve sonuçlar incelenmiştir.

Gelişen teknoloji ve internet çağı sayesinde tüketicilerin tutumu da değişmiş, tüketiciler çevrimiçi alışveriş alışkanlığını edinmiştir. Durum böyle gelişince ticaret kuruluşları "e-ticaret" adı altında online alışveriş imkânı sağlamış olup bu döngüyü ivmeli şekilde geliştirmektedir. Gelişen e- ticaret sektörü sayesinde rekabet de artmıştır. Firmalar en iyi olabilmek, mevcut müşterilerini koruyup pazarını daha da artırmak için yarış halindedir. Bu sirkülasyonda optimum sonuçlar elde etmek için eticaret siteleri müşterilerin sesini iyi dinlemektedir. Müşterilerin önceliği, kullandıkları web sitesininin kolaylığı ve alışverişin güvenilir şekilde gerçekleştirilebilmesidir.

$\mathrm{Bu}$ çalışmada, e-ticaret sitelerinin kullanılabilirliği çoklu karar verme yöntemlerinden AHP ve TOPSİS ile değerlendirilmiştir. Site trafiği en yoğun olan 10 e-ticaret sitesi belirlenip ardından literatür taramasına göre kullanıcıların ve tasarımcıların en çok tercih ettiği 7 kriter ile problemin çözümüne gidilmiştir. AHP ve TOPSİS yöntemleri uygulanırken site tasarımında uzman kişilerin görüşleri ve çalışmada uygulanan anket çalışmasına göre müşterilerin beklentileri dikkate alınarak çapraz kıyaslamalar yapılıp sonuçlar ele alınmıştır.

Elde edilen sonuçlara göre kullanıcıların e-ticaret sitesi seçerken en çok dikkat ettiği kriter site navigasyonu, en az önem verdiği kriter ise bilgi kalitesi olarak bulunmuştur. Kullanıcılar alışveriş yaparken sitede kolay gezinmek istemektedir. Belirlenen kriterler ve alternatifler doğrultusunda AHP analizine göre kullanılabilirlik 
puanı en yüksek olan siteler n11 ve Trendyol; en düşük puana sahip site Apple olmuştur. Udemy ve GittiGidiyor siteleri değerlendirmeye göre yüksek puanlarla yakın bir performans sergilimektedir. Çalışmada uygulanan TOPSİS yöntemi ile sonuçlarda farklılaşma olduğu görülmüştür. Ağırlıklı tablo hesaplamalarına göre kullanılabilirliği en iyi olan siteler Sahibinden, AliExpress ve Amazon olurken, en düşük performansa sahip site ise Apple olmuştur.

Dijitalleşen dünyada pazarda yer almak şirketlerin online platformlarda yer alması kaçınılmaz bir koşuldur. Müşteriler eticaret sitesi üzerinden firmaları tanır ve buna göre alışveriş tercihlerini belirler. $\mathrm{Bu}$ araştırmanın sonuçlarında tüketicilerin büyük çoğunluğunun e-ticaret sitelerinde alışveriş yapma sıklığının önemli ölçüde arttığı görülmektedir. Geleneksel mağaza anlayışının dışında firmaların web sitesi ve mobil cihazlardaki yüzü potansiyel müşterilerini belirler. Site tasarımı, ödeme kolaylığg, ürün çeşitliliği ve ürün bilgileri, hizmet kalitesi siteyi tercih etme davranışını etkilemektedir.

Çok kriterli karar verme problemleri kullanılarak nesnel yaklaşımlarla alternatif yol izlenip seçim yapılmıştır. Belirlenen kriterler arasında hiyerarşik yapı dikkate alınarak çalışmanın amacına uygun AHP ve TOPSİS tercih edilmiştir. Çalışmanın, kullanılan matematiksel yöntemlerle ileride yapılacak çalışmalara yön verebileceği öngörülebilir.

$\mathrm{Bu}$ çalışmanın sonuçlarında, satın alma niyetinin sadece ürün özelliğine bağlı olmadığı, erişilebilirliği ve kişisel asistanların sunduğu hizmeti de kapsadığı görülmektedir. Ayrıca tüketicilerin alışveriş yapma niyetlerinin değiştiği sonucuna varılmıştır. Firmalar, e-ticarette birçok ürün ve hizmet konsepti arasındaki rekabeti maksimum optimizasyon seviyesinde tutabilmek için mobil uygulamalarını ve kullanılabilirliklerini güncel tutmalıdır.

\section{Kaynakça}

Adepoju, S. A., Oyefolahan, I. O., Abdullahi, M. B., \& Mohammed, A. A. (2020). MULTI-CRITERIA DECISIONMAKING BASED APPROACHES IN WEBSITE QUALITY AND USABILITY EVALUATION: A SYSTEMATIC REVIEW. Journal of Information and Communication Technology, 19(3), 399-436.

Adıgüzel, A. T. (2010). Sanal Mağaza Atmosferini Etkileyen Özellikler ve Tüketici Tercihleri Üzerindeki Rolü: Online Tüketiciler Üzerine Bir Araştırma. (Yüksek Lisans Tezi). Balıkesir: Balıkesir Üniversitesi, Sosyal Bilimler Enstitüsü.

Aksoy, R. \& Sever, H. (2012). Elektronik Pazarlarlarda Güven Problemi ve Kriminal Faaliyetler. Electronic Journal of Vocational Colleges, 2 (1), 154-164.

Armağan, E. A. \& Turan, A. H. (2014). İnternet Üzerinden Alışveriş: Demografik Faktörlerin, Bireysel İhtiyaçların Etkisi Üzerine Ampirik Bir Değerlendirme. Atatürk Üniversitesi İktisadi ve İdari Bilimler Dergisi, 28 (3), 1-22.

Arora, M. (2016). Selection of parameters of E-commerce websites using AHP. In Proceeding of 2nd Conference on Innovative Practices in Information Technology \& Operations Management (pp. 22-27).

Aydın, S., \& Derer, E. (2015). E-Ticarette Güven Unsurunun Müşterilerin Satın Alma Davranışlarına Olan Etkisi: Süleyman Semirel Üniversitesi Öğrencileri Üzerine Bir Araştırma. Journal of Suleyman Demirel University Institute of Social Sciences, 21(1), 127-150.
Aziz, U. A., Wibisono, A., \& Nisafani, A. S. (2019). Measuring the quality of e-commerce websites using analytical hierarchy process. Telkomnika, 17(3), 1202-1208.

Calisir, F., Bayraktaroğlu, A. E., Gumussoy, C. A., Topcu, Y. I., \& Mutlu, T. (2010). The relative importance of usability and functionality factors for online auction and shopping web sites. Online Information Review.

Cesur, Z., \& Tayfur, G. (2015). İnternetten Alışveriş Davranışında Alg1lanan Tüketici Riskleri: Üniversite Öğrencileri Üzerinde Bir Araştırma. Meslek Dergisi, 5(1), 19-33.

Coşkun, R . (2019). A New Fuzzy Based Marketing Performance Measurement Model with a Real Case Study. Econder International Academic Journal, 3 (1), 41-73.

Çetin, H. (2014). Online (Çevrim İçi) Alışverişte Akademisyen Davranışları ve Alışverişe Yönelten Etkenler. Süleyman Demirel Üniversitesi İktisadi ve İdari Bilimler Fakültesi Dergisi, 19(4), 65-76.

Doğaner, M. (2007). Elektronik Ticaret Türkiye'de Elektronik Ticaretin Gelişimi ve İşletmeden Tüketiciye Elektronik Ticaret Üzerine Bir Araştırma (Yüksek Lisans Tezi). Konya: Selçuk Üniversitesi, Sosyal Bilimler Enstitüsü

Doğrul, Ü. (2012). Elektronik Alışveriş Davranışında Faydacı ve Hedonik Güdülerin Etkisi. Sosyal ve Beşeri Bilimler Dergisi, 4(1), 321-331.

Dulkadir, B., \& Akkoyun, B. (2013). Elektronik Ticaretin İşletmelerin Dış Çevresi Açısından Değerlendirilmesi: Malatya İli Tekstil Sektöründe Bir Uygulama. Dicle Üniversitesi İktisadi ve İdari Bilimler Fakültesi Dergisi, 2(6), 1-14.

Durmaz, Y., İlhan, A., \& İnce, E. (2015). Theoretical Approach to Online Marketing. International Journal of Computers \& Technology, 14(11), 6244-6249.

Durmuş, M., \& Tayyar, N. (2017). AHP ve TOPSIS ile Farklı Kriter Ağırlıklandırma Yöntemlerinin Kullanılması ve Karar Verici Görüşleriyle Karşılaştırılması. Eskişehir Osmangazi Üniversitesi İktisadi ve İdari Bilimler Dergisi, 12(3), 65- 80.

Dündar, S., Fatih, E., \& Özdemir, Ş. (2007). Fuzzy Topsis Yöntemi İle Sanal Mağazalarin Web Sitelerinin Değerlendirilmesi. Atatürk Üniversitesi İktisadi ve İdari Bilimler Dergisi, 21(1), 287-305.

Ertemel, A. V., \& Celik, B. (2016). An exploratory analysis of online shopping behavior in Turkey. International Journal of Commerce and Finance, 2(1), 67-80.

Fernandes, F. R., \& Paschoarelli, L. C. (2014, June). Online Shopping Websites: An Evaluation of User Experience and Interface Ergonomic Criteria from the Perspective of Older Users. In International Conference of Design, User Experience, and Usability (pp. 104-115). Springer, Cham.

Gümül, F. (2015). Tüketicilerin İnternetten Alışveriş Davranışını Etkileyen Faktörler: Yüzüncü Y1l Üniversitesi Öğretim Elemanları Üzerinde Bir Uygulama (Yüksek Lisans Tezi). Van: Yüzüncü Y1l Üniversitesi, Sosyal Bilimler Enstitüsü.

Hayran, S., Gül, A., \& Duru, S. (2017). Türkiye'de İnternetten Alışveriş Yapan Bireylerin Risk Algılarının Cinsiyet Farklılıklarına Göre Değerlendirilmesi. Electronic Journal of Vocational Colleges, 48-57.

Kahraman, C., Onar, S. Ç., \& Öztayşi, B. (2018). B2C marketplace prioritization using hesitant fuzzy linguistic AHP. International Journal of Fuzzy Systems, 20(7), 22022215.

Kang, D., Jang, W., \& Park, Y. (2016). Evaluation of e-commerce websites using fuzzy hierarchical TOPSIS based on ESQUAL. Applied Soft Computing, 42, 53-65. 
Lai, I., HUANG, Y. F., SIANG, J. H., \& WENG, M. W. (2020). Evaluation of Key Success Factors for Web Design in Taiwan's Bike Case Study. The Journal of Asian Finance, Economics, and Business, 7(11), 927-937.

Lin, H. F. (2010). An application of fuzzy AHP for evaluating course website quality. Computers \& Education, 54(4), 877888.

Masudin, I., \& Saputro, T. E. (2016, February). Evaluation of B2C website based on the usability factors by using fuzzy AHP \& hierarchical fuzzy TOPSIS. In IOP Conference Series: Materials Science and Engineering (Vol. 114, No. 1, p. 012091). IOP Publishing.

Nagpal, R., Mehrotra, D., \& Bhatia, P. K. (2016). Usability evaluation of website using combined weighted method: Fuzzy AHP and entropy approach. International Journal of System Assurance Engineering and Management, 7(4), 408417.

Omurbek, N., \& Simsek, A. (2014). Selection of online shopping site based on analytic hierarchy process and analytic network process methods. Yönetim ve Ekonomi Araştırmaları Dergisi, 22, 306-327.

Ozok, A. A., \& Wei, J. (2010). An empirical comparison of consumer usability preferences in online shopping using stationary and mobile devices: results from a college student population. Electronic Commerce Research, 10(2), 111-137.

ÖZKAN, N. F., \& YAVUZ, F. G. (2019). USINGG FUZZY TOPSIS AND REGRESSION BASED WEIGHTS TO RANK ECOMMERCE WEBSITES. Eskişehir Osmangazi Üniversitesi Mühendislik ve Mimarlık Fakültesi Dergisi, 27(2), 116-124.

Rouyendegh, B. D., Topuz, K., Dag, A., \& Oztekin, A. (2019). An AHP-IFT integrated model for performance evaluation of Ecommerce web sites. Information Systems Frontiers, 21(6), 1345-1355.

Roy, S., Pattnaik, P. K., \& Mall, R. (2017). Quality assurance of academic websites using usability testing: an experimental study with AHP. International Journal of System Assurance Engineering and Management, 8(1), 1-11.

Shin, J. I., Chung, K. H., Oh, J. S., \& Lee, C. W. (2013). The effect of site quality on repurchase intention in Internet shopping through mediating variables: The case of university students in South Korea. International Journal of Information Management, 33(3), 453-463.

Sukrat, S., \& Papasratorn, B. (2018). An architectural framework for developing a recommendation system to enhance vendors' capability in $\mathrm{C} 2 \mathrm{C}$ social commerce. Social Network Analysis and Mining, 8(1), 1-13.

Sun, C. C., \& Lin, G. T. (2009). Using fuzzy TOPSIS method for evaluating the competitive advantages of shopping websites. Expert Systems with Applications, 36(9), 1176411771.

Supçiller, A , Bulak, M . (2020). Mobil Uygulamaların Performanslarının Veri Zarflama Analizi ile Değerlendirilmesi. Gümüşhane Üniversitesi Fen Bilimleri Enstitüsü Dergisi, 10 (3), 711-723.

Şimşek Yağlı, B., \& Yalçın, N. (2018). ISO 25010 kalite modeli çerçevesinde teknoloji mağazalarının internet sitelerinin çok kriterli analizi: Türkiye örneği (Master's thesis, Nevşehir Hacı Bektaş Veli Üniversitesi). 